\title{
Uppslagsrika analyser av finländsk samtidslitteratur
}

\author{
Leena Kirstinä (red.): Nodes of Contemporary Finnish Literature. Studia Fennica Litteraria 6. \\ Helsingfors: SKS, 20I3. $197 \mathrm{s.}$
}

Den inhemska litteraturen väcker numera ett relativt brett internationellt intresse, inte minst genom deckargenren där Nordic noir fătt stort genomslag. Att placera finländsk litteratur $i$ ett internationellt sammanhang och samtidigt föra ut finländsk litteraturforskning internationellt är därför angeläget. Antologin Nodes of Contemporary Finnish Literature, redigerad av professor emerita Leena Kirstinä, svarar på ett behov av att granska samtidslitteraturen i ett internationellt perspektiv. Volymen presenterar i en introducerande översikt samt nio referee-granskade artiklar en rad vändpunkter i samtida finländsk skönlitteratur. De nio artiklarna spänner över postmodern allegori, feministiskt berättande, historiografi, självbiografi, det moderna subjektet, metalyrisk poesi, realism, barnlitteratur och intertextualitet. En gemensam utgångspunkt är att 1980-talet innebar en rejäl omvärdering av berättandets premisser, då modernism stöts mot postmodernism. Ambitionsnivån är hög och artiklarna synnerligen läsvärda. Den grundliga teoretiska förankringen borgar för användbarhet i både undervisning och forskning och ger impulser till att utforska andra verk med motsvarande produktiva begreppsapparat.

I sin introduktion kontextualiserar Leena Kirstinä den finländska samtidslitteraturen. Hon pekar på de senaste decenniernas skiftande villkor, exempelvis nyliberalismens genomslag under 1990-talet samt teoriutvecklingen i bland annat filosofi, sociologi och litteraturvetenskap som starkt influerat skönlitteraturen. De noder Kirstinä särskilt betonar på basen av artiklarna är outsidern, jag-berättandet, nyliberalismen och familjeskildringen.

Brian McHale och Randall Stevensons The Edinburgh Companion to Twentieth-Century Literatures in English (2006) är en ledstjärna för antologiupplägget. Deras nyorientering av litteraturhistorieskrivningen frångår ett traditionellt tänkande baserat på nationalitet, decennier och litterära rörelser till förmån för en spatial litteraturhistorieskrivning där knutpunkter kartläggs. Dessa knutpunkter, vändpunkter eller noder är viktiga i egenskap av att de är tematiska mötesplatser som överskrider tid och rum. Att fokusera på noder skapar dessutom intrikata diskussioner som i hög grad berör epistemologiska frågeställningar om verklighet och verkets representationalitet. Men vad är då en nod? Är den detsamma som en avvikelse? Utgörs noderna av undantag som blir stilbildande vändpunkter som för skönlitteraturen i nya riktningar? Här hade det varit stimulerande att fă en fördjupad diskussion kring själva nyckelbegreppet. 
Artiklarna är överlag av mycket hög kvalitet. Exempelvis Mari Hatavara tar sig an postmodern historisk roman genom att visa hur motsägelser, multipelt berättande och modus, och inte minst jag-perspektiv, förändrar genren i samklang med hur synen på historieskrivning har utvecklats. Artikeln är avklarnad, teorin sömlöst infogad i en elegant och intresseväckande framställning där tre verk, Juha Seppälas Suomen historia (1998), Ralf Nordgrens Det har aldrig hänt (1977) och Irja Ranes Naurava neitsyt (1996) analyseras med Linda Hutcheons begrepp historiografisk metafiktion som huvudsakligt analysverktyg. Pirjo Lyytikäinen å sin sida går i sin analys av Leena Krohns roman Tainaron (2004) som skildrar ett posthumant insektsamhälle i dialog med Brian McHale och nyanserar föreställningarna om metaforik och "blandade rum". Fram träder en gäckande bild av hur Krohn återanvänder sig av doxa om insekters annorlundahet i sin roman.

I antologin är samtidskontextualiseringen starkt närvarande, vilket särskilt Jussi Ojajärvi illustrerar då han sätter fingret på hur nyliberalismen och post-industrialiseringens konsumtionskulturer syns i finländska romaner genom att ta fasta på kategorin familj. Bland annat läser han Kjell Westös roman Drakarna över Helsingfors (1996) ur detta produktiva perspektiv. Genomgående integreras litteratur skriven på svenska i Finland och flera av artiklarna tar avstamp i finlandssvenska romaner som utgör noder, exempelvis Monika Fagerholms Diva (1999), förtjänstfullt analyserad av Kristina Malmio, som tar fasta på romanens användning av populärlitteratur som ett grepp som överskrider romanens mer lokala litterära sammanhang och placerar det $i$ en internationell kontext.

Två artiklar bryter mot mönstret att vara teoribaserade och gå på djupet med en avgränsad frågeställning. Den ena är Päivi HeikkiläHalttunens översikt av i första hand finskspråkig barnlitteratur. I sig är artikeln en god introduktion med en rad insiktsfulla påståenden om samtidslitteraturens särdrag. Ställvis făr framställningen ändå en slagsida av klagolåt, vilket hade kunnat undvikas genom ett stramare teoretiskt grepp. Det är olyckligt att just barnlitteraturen inte får en teoretisk inramning eftersom teoriutvecklingen på fältet just där är dynamisk. Den andra översiktsartikeln, Outi Ojas exposé över finländsk poesi tecknar intressanta sammanhang som att finländsk samtidspoesi framstår som megamaskulin tills kvinnliga poeter bryter in med polemiska dramatiska monologer. Finländsk poesi, som drabbades hårt av förlagsbranschens kris, reste sig genom poesiuppläsningar och myllrande aktivitet. De finlandssvenska poeterna integreras dessvärre inte i framställningen, vilket kunde ha gett en något annorlunda bild. I övrigt spåras tendenser som autofiktivitet, dramatisk monolog, digitaliseringens återverkningar och nyromantiska skiftningar i ett litteraturfält som är en pigg lekplats med ett rikt bildflöde. 
Nodes of Contemporary Finnish Literature är en ambitiös och uppslagsrik antologi. De sammangyttringar som valts för djupare studium placeras både i sina litterära och i nyskapande teoretiska sammanhang. Sammantagna utgör artiklarna en stimulerande kartritning över nuläget $\mathrm{i}$ finländsk skönlitteratur. På bästa sätt genererar antologin läslust och inte minst lust att följa i de teoretiska spår som här presenteras.

\section{Skribent}

Mia Österlund, docent, universitetslärare, Åbo Akademi, litteraturvetenskap (mosterlu[at]abo.fi)

\section{Suomalainen tekijäpeli ranskalaisin säännöin}

Kaisa Kurikka: Algot Untola ja kirjoittava kone. Turku: Eetos, 20 I 2. 349 s.

Kaisa Kurikan väitöskirja alkaa luettelolla Algoth Tietäväiseksi ristityn miehen monista myöhemmistä nimistä. Luettelo lähtee liikkeelle ensimmäisestä itse otetusta nimestä Algot Untola, joka tutkimuksessa muodostaa sateenvarjon tekijyyden kokonaisuudelle. Yhteensä nimiä oli yli neljäkymmentä. Parhaiten näistä kirjailijana tunnetaan Maiju Lassila, mutta myös Irmari Rantamalan nimissä julkaistiin viisi romaania ja J.I. Vatasen nimissä yksi. Muut nimet esiintyivät julkaisemattomien käsikirjoitusten nimiölehdillä, lehtikirjoituksissa, kirjeiden allekirjoituksissa.

Kurikan väitöstutkimuksessa suhteutetaan eri tekijänimiä toisiinsa, tehdään erontekoja ja samastuksia, "kartografiaa tekijästä käsitteellisenä henkilönä" (s. 35). Käytännössä muotoilu tarkoittaa sitä, että sekä Untolan tekijyyksien kautta että teosten sisäisten kirjailijahahmojen kautta eritellään tekijyyden eri puolia, siihen kohdistuvia odotuksia ja erilaisia tekijyyden mahdollisuuksia.

Väitöskirja alkaa provokatorisesti Untolan kuolemasta vuonna 1918 epämääräisissä olosuhteissa. Untola oli syytettynä kirjoittamistaan vääristä sanoista, poliittisesta vääräoppisuudesta. Untola, elävä ruumis eri tekijänimien takana, kuoli, vaikka allekirjoituksena tuomion tuoneessa tekstissä oli Irmari Rantamala. Aloitus kyseenalaistaa tekijän 